\title{
The Meaning of Traditional Graduation in Lekuk 50 Tumbi Lempur Community, Kerinci Regency, Jambi Province
}

\author{
Yolla Ramadani ${ }^{1}$, Astrid Qommanecci ${ }^{2 *}$ \\ STIE Sakti Alam Kerinci \\ yolla_ramadani@yahoo.com
}

Artikel ini merupakan hasil penelitian yang dilakukan dengan tujuan untuk mengetahui makna dari tradisi wisuda secara adat yang masih dilaksanakan oleh masyarakat Lekuk 50 Tumbi Lempur sampai saat ini. Tradisi wisuda secara adat adalah tradisi pemberian gelar kepada putra dan putri masyarakat Lekuk 50 Tumbi Lempur yang telah memperoleh gelar sarjana baik sarjana, pascasarjana dan doktoral oleh Depati Nan Sepuluh. Tradisi ini dilakukan setiap tahun pada tanggal 2 Syawal atau bertepatan dengan Idul Fitri di Gedung Serba Guna Desa yang ditentukan. Penelitian ini menggunakan metode kualitatif deskriptif dimana data dikumpulkan dengan observasi, wawancara dan studi dokumentasi Hasi penelitian menunjukkan bahwa serangkaian proses kegiatan dilakasanakan untuk prosesi pengukuhan gelar wisudawan. Gelar sarjana Strata Satu akan dikukuhkan sebagai Cendikionegaro, Strata Dua akan diberi gelar Cendikionegaro Pertamo, dan Strata Tiga/Guru Besar akan diberi gelar Cendikionegaro Utama. Dari hasil penelitian dapat dilihat bahwa tradisi wisuda secara adat memiliki makna bagi masyarakat Lekuk 50 Tumbi Lempur diantaranya adalah sebagai wujud penghargaan yang diberikan oleh Depati nan Sepuluh agar putra dan putri Lempur bisa berbangga atas prestasi yang mereka peroleh. Selain prestasi dan gelar sarjana yang mereka peroleh melalui wisuda secara adat juga salah satu bentuk pengakuan gelar mereka di masyarakat. Gelar ini nantinya diharapkan bisa menjadi motivasi bagi putra dan putri Lekuk 50 Tumbi Lempur untuk dapat menggapai cita-cita mereka dan meraih kesuksesan di masa yang akan datang.

This article is the result of research conducted aiming to find out the meaning of customary graduation tradition that is still being carried out by Lekuk 50 Tumbi Lempur community until now. This traditional graduation is being held by Depati Nan Sepuluh (The Ten Leaders) to give titles to the sons and daughters of Lekuk 50 Tumbi Lempur community who have already obtained educational degree e.g. bachelor degree, master's degree, and doctoral degrees. They celebrate this every year on 2 Shawwal or coinciding with Eid al-Fitr at some specified Village Hall. This research uses descriptive qualitative method where data was collected through observation, interview and documentation study. Result shows that series of activity process are being done for the inauguration procession. Bachelor's degree holders will be confirmed as Cendikionegaro, while Master's degree holders as Cendikionegaro Pertamo and Post Graduates degree holders/Professors as Cendikionegaro Utama. From the results of this study, it can be seen that the tradition of this customary graduation has a special meaning for the society of Lekuk 50 Tumbi Lempur as a form of appreciation given by The Ten Leaders so that the sons and daughters of Lempur is honoured and proud of their achievements. In addition to the achievements and degrees that they obtained, it was also a form of recognition of their degree in the society. This customary title is expected to motivate the sons and daughters of Lekuk 50 Tumbi Lempur to reach their goals and achieve success in the future.

Keyword: meaning, education, traditional graduation, customary graduation

Proses Review : 1 - 28 Januari 2020, Dinyatakan Lolos: 10 Februari 2020 


\section{INTRODUCTION}

Cultures are patterns of behavior that are packaged in a symbol system then historically transmitted to others. The system is a legacy of innate concepts which are also expressed through meaningful symbols so they can be communicated (Koenjaraningrat, 1972: 68). Sociologists Ogburn and Nimkof provides the best way to view cultures in society in two forms, namely material cultures and non-material cultures. Material cultures are physical evidences of the existence, identity, characteristics of a particular group or community of a society. While non-material cultures consist of abstract objects that are not tangible, such as customs, traditions, habits, behavior, attitudes, beliefs, language, art, law, religion, and so forth (Saifuddin, 2005: 134).

Lekuk 50 Tumbi Lempur community, located in Gunung Raya District, Kerinci Regency, Jambi Province, is one of the communities that still maintains their cultures both materially and non materially. Gunung Raya District is an area with topography of a plain with a geographical location of $890 \mathrm{~m}$ above sea level. Gunung Raya district has an area of 74,385 ha or $19.53 \%$ of the area of Kerinci Regency which is 380,850 ha with an altitude between 950 to 1200 meters above sea level. (Benjamin, 2005).

This customary traditional graduation is often referred to as education day at the Lekuk 50 Tumbi community. It motivates local children to continue their education until colleges/higher education. Even though they live in the periphery area, they are always updated in the development of science and technology. This tradition is included as a nonmaterial culture that is still carried out by the community today.

This customary graduation tradition is celebrated by public every year on the 2 nd of Shawwal. This tradition has been going on for \pm 58 years since 1960 and is celebrated by the community on a large scale by customarily establishing the sons and daughters of Lekuk 50 Tumbi Lempur who have completed their studies. When we did our preliminary observation of this tradition implementation in 2017 , there are quite a lot of people who were traditionally confirmed as "cendikionegaro"(traditional title), namely 654 undergraduate (S1), 63 people with master's degree (S2), 12 people with doctoral degree (S3) and 6 professors. As a comparison, until 2018 there are more than 800 children from Lekuk 50 Tumbi Lempur community who have obtained bachelor's degrees, and most of them have been traditionally confirmed each year.

Based on the research background, we can see that Lekuk 50 Tumbi Lempur community are still very dense in carrying out ancestral traditions. In addition, this area is on the outskirts of Kerinci Regency, which in general, the level of education of people in area on the outskirts of city center

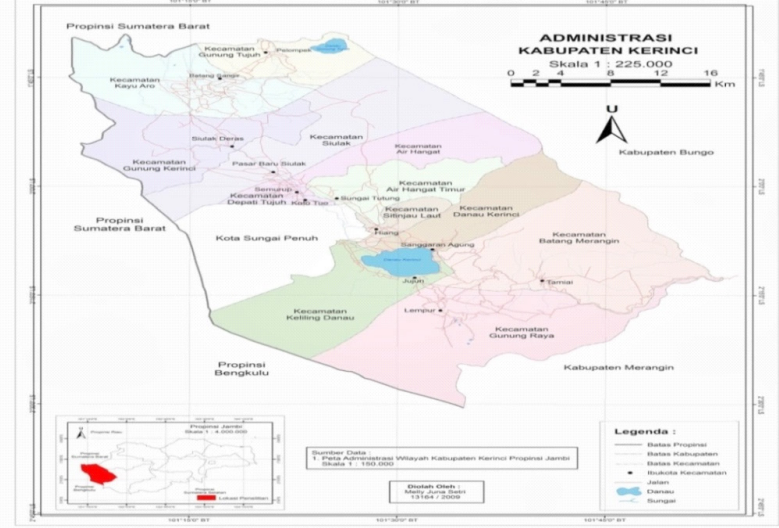

Figure 1. Map of the regency of Kerinci

will be lower than ones in the city center (Damsar, 2011: 56). This condition did not happen in Lekuk 50 Tumbi Lempur community, even though they are located on the outskirts of Kerinci district directly opposite the TNKS forest, they do have high education level, sometimes exceeding community at the district center.

It is indeed very interesting to be further investigated, what causes the community to still carry out this customary graduation tradition up until now? Thus, the purpose of this study is to see how the existence and the meaning of this graduation tradition implementation in Lekuk 50 Tumbi Lempur community.

\section{METHOD}

This research uses descriptive qualitative method where data is collected through observation (involved observation), interview, and documentation study. Data analysis in qualitative research is carried out at time the data collection takes place, and after the data collection is completed within a certain period. The process of data analysis continuously takes place during study conducted using interactive analysis models from Miles and Huberman as stated in Bungin (2005: 69), including data reduction, data presentation, and drawing conclusions. Study was conducted from April to September 2019 taking place of research in Kerinci Regency, precisely at Lekuk 50 Tumbi Lempur, Gunung Raya District.

\section{RESULTS AND DISCUSSION}

Traditional History of Graduation Traditions Graduation tradition is traditionally referred by the people of Lekuk 50 Tumbi Lempur as an educational day. Majority of people in Lekuk 50 Tumbi Lempur live by farming the fields. Most people plant Cassiavera (Cinnamon), since around the 1950s price of cinnamon is still very high, thus by farming alone the community can fulfill their daily needs quite luxuriously. This makes people reluctant to go to school let alone go to tertiary institutions/higher education because they don't think that higher education is 


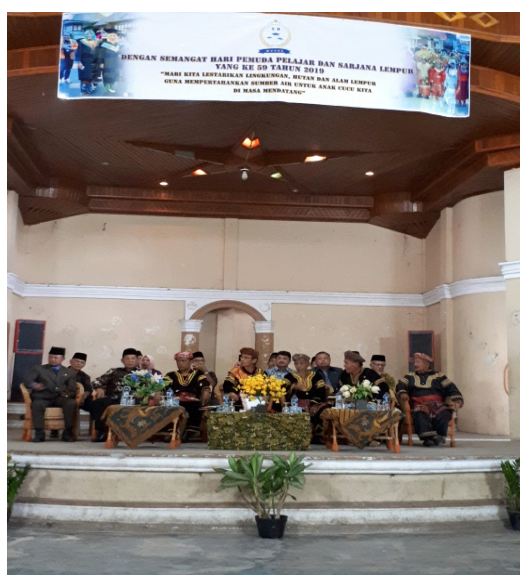

Figure 2. The Tens Leaders

needed as by doing farming is enough for them to earn quite a lot of money.

In 1961, the first scholar appeared at Lekuk 50 Tumbi Lempur: Ir. Rifa'i. He slaughtered a buffalo in order to celebrate thanksgiving to expresshis gratitude to God towards the title he had obtained. He also held a festivity inviting traditional leaders and the villagers. The emergence of this scholar rose a thought on traditional leaders' mind that other communities should also have the desire to continue their education. Therefore, Customary Institution has agreed to hold Student Day as a form of an anniversary of Youth, Students and Bachelors' degree holders of Lekuk 50 Tumbi Lempur every year. This year 2019 is the 58th implementation of the traditional graduation where there are more than a thousand scholars have been recorded in Lekuk 50 Tumbi Lempur community.

The Nature of Traditional Graduation Traditions

Traditional graduation (commonly known as Youth, Students, and Bachelor's Education Day) has become a habit for the people of Lekuk 50 Tumbi Lempur every year. The implementation of this tradition is being carried out in a lively manner.

Time and Place of Implementation

This traditional graduation ceremony is being held on the 2nd of Syawwal month each year, and takes place in the selected Multipurpose Village Building. Presently, there are 5 (five) multipurpose buildings located in each village of Lekuk 50 Tumbi Lempur. The customary graduation tradition is being held alternately in those five villages every year. This year, the graduation tradition is being held at the Multipurpose Building in Lempur Mudik Village.

Implementation of the Customary Graduation Tradition The customary graduation tradition is carried out annually by a committee appointed by the Curatorial Board. The Curatorial Board consists of Chiefs of Villages included in Lekuk 50 Tumbi Lempur. This Curatorial Board will later be the coordinator of traditional graduation activities.

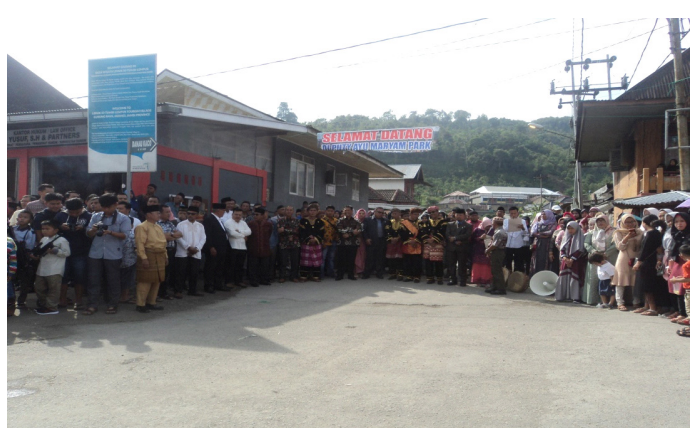

Figure 3. Opening by the Ten Leaders

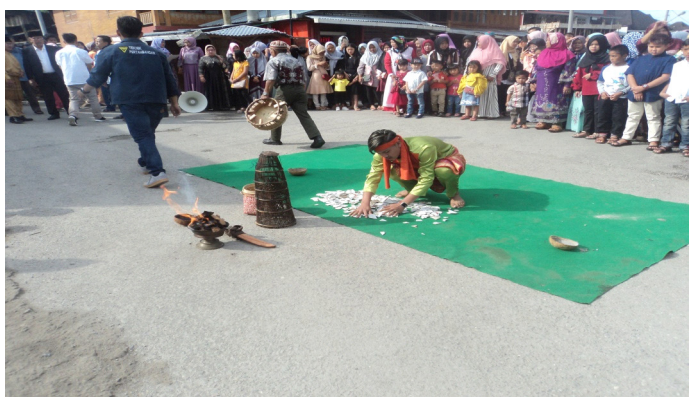

Figure 4.Asyeik Dance

The customary graduation ceremony begins by forming a committee appointed by the Curatorial Board under the approval of Depati Agung (The Great Leader). After the elected committee is formed, this committee will then hold a work meeting later to discuss all the preparations and equipments that will be needed to implement the activities. This graduation tradition actually has several series of activities including the following:

\section{Registration of Graduates}

Registration for graduation participants is now customary and can be done online. This development was carried out because there were so many sons and daughters of Lekuk 50 Tumbi Lempur who continued their education outside the region so that online registration made it easier for them to register remotely. Previously, every graduation participant would pay a registration fee of Rp. 50,000 for consumptions and other needs. But at this time, the committee always gets subsidies and aids from the sons and daughters of Lekuk 50 Tumbi Lempur who have already being successful out there, thus each participant will be traditionally graduated for free, no need to pay the registration fee.

\section{Opening by The Ten Leaders}

The traditional graduation ceremony was held in the middle of Lekuk 50 Tumbi Lempur village. All graduates, graduating families and the community gathered to witness the customary opening ceremony. All graduates wore Toga (graduation clothes) from their respective colleges. There were several activities in the opening ceremony including remarks from the Committee, the handover of the graduates from the committee to Depati Nan X, Asyeik Dances and continued with parading of all graduates around the villages in the Lekuk 50 area of Tumbi Lempur. 


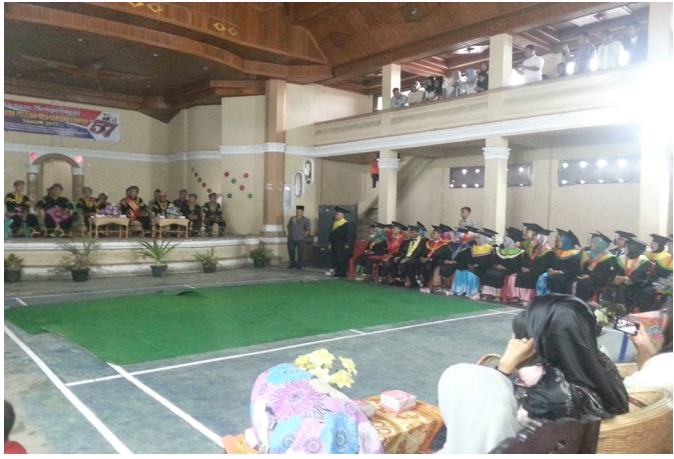

Figure 5. Traditional Graduation Ceremony

The graduation procession will end at the multipurpose building where the event takes place.

\section{Traditional Graduation Ceremony}

All Graduates and families are gathered in the Multipurpose Building to facilitate traditional ceremonial activities. The customary graduation procession is the same as the graduation ceremony conducted at the University, only the awarding titles are given in a customary manner. Series of events began with a report from head of the committee, starting with reading the graduates' names by The Ten Leaders, as well as giving custom titles to the graduates. There are some different awards given to graduates, e.g. Bachelor's Degree graduates are awarded Cendikionegaro title, Masters' degree graduates are awarded as Cendikionegaro Pertamo, while Doctoral Degree graduates and Professors are awarded as Cendikionegaro Utama.

After this procession, the awarding was continued by letting the graduates to say thank you for their parents. This traditional graduation procession ceremony is concluded by a scientific speech carried out by one of the best graduates of the sons and daughters in Lekuk 50 Tumbi Lempur.

\section{Thanksgiving Celebration}

After the series of events in the multipurpose building ended, the graduates and their families returned to their homes to prepare a celebration for the Ten Leaders and all the people who come to visit to the graduates' house. Usually graduates will divide their celebration into several times: in the afternoon, at night, even continued till the next day if there are too many graduation celebrations to be done in one day. The Ten Leaders will share their part to be able to attend from graduates' house to house. Thankgiving celebration is being held in a lively manner in every house, even they kill a buffalo when they afford it, and cook it for the celebration.

Some of the series of activities mentioned above have become a routine every year by Lekuk 50 Tumbi Lempur community. The Second of Shawwal is awaited as a big day for prospective graduates.

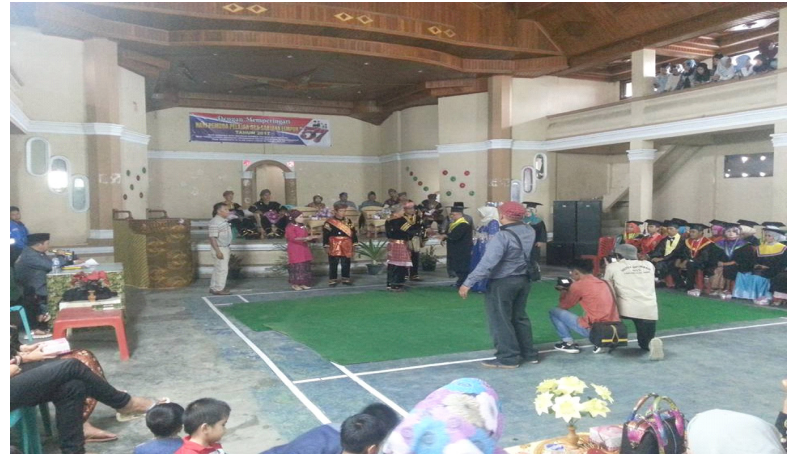

Figure 6. Awards

The Existence of Customary Graduation Traditions The customary graduation tradition is a tradition intentionally made by the ancestors of Lekuk 50 Tumbi Lempur community. Based on interviews with several informants, this tradition was deliberately created to change the mindset of people who used to be very enthusiastic about becoming a farmer because of the good geographic nature of Lekuk 50 Tumbi area. Previously, most people planted cinnamon (Cassiavera) since its price was quite expensive. As a result, people were reluctant to continue their education and choose to be farmer instead.. Lempur community is indifferent to the idea of having a higher education as by planting cinnamon, they already get a lot of money to finance their life and meet their daily needs. This mindset makes the Ten Leaders along with other Customary Leaders think hard on how their community can continue their education so that people of Lekuk 50 Tumbi are not far behind society development.

The graduation tradition is a tradition that still survives and is routinely carried out by the people of Lekuk 50 Tumbi Lempur until now. In its development, there is no fundamental change in every activity that are being carried out. Based on information from several different informants, their generation said that there was no significant difference in the implementation of traditional graduation in the current generation (on Eid Al-Fitr 2018 yesterday) with the traditional graduation traditions they had experienced and carried out before 2018. The traditional graduation carried out by the Lekuk 50 Tumbi Lempur community is a model of an expression of actions taken when they have completed their education, while the meaning and values contained in the graduation tradition are customary and believed by the local community as a model for interpreting, encouraging, and creating actions or in other senses as guidelines for action.

The customary graduation tradition as a system of meaning and system of value, associated with symbols contained in this tradition, that is, symbols of titles that have been given. The titles which are inaugurated by The Ten Leaders are what the sons and daughters of Lekuk 50 Tumbi Lem- 


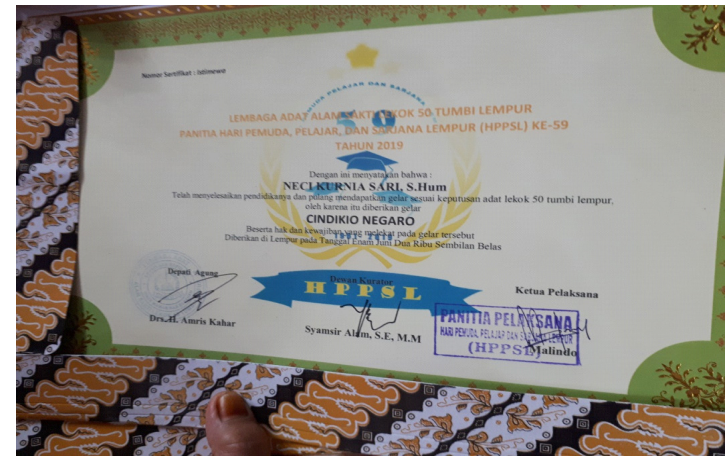

Figure 7. An Example of Cendikionegaro Certificate

pur being proud of in their daily lives. Interpretive theory emphasizes the importance of the particularity of a culture, and holds that the central objective of social study is an interpretation of meaningful human practices. Human-generated culture has a meaning that starts from community interpretation of the culture that is believed and reflected in various forms of activities or activities that they do.

The traditional graduation performed in Lekuk 50 Tumbi Lempur community is a tradition that has its own meaning. In its implementation, it certainly starts from the interpretation of the supporting community, and is reflected through practices or activities related to the tradition, such as the enthusiasm of the children in the community to be able to continue higher education.

Geertz clearly defines it. Culture is a system of meanings and symbols arranged, in a sense that individuals define their world, express their feelings and give their judgments; a pattern of meaning transmitted historically manifested in symbolic forms through the means by which people communicate, perpetuate, and develop their knowledge and attitudes towards life; a collection of symbolic tools for regulating behavior, extrasomatic sources of information. Because culture is a symbolic system, cultural processes must be read, translated, and interpreted.

Geertz focuses the concept of culture on cultural values that guide society to act in dealing with various problems of his life. Therefore, in the end, the concept of culture is acting more as a guideline for evaluating symptoms understood by the perpetrators of that culture. The meaning contains evaluations of actors in the culture. In culture, meaning is not individual but public, when the meaning system then becomes collective property of a group. Culture becomes a pattern of meaning which continues historically manifested in symbols. Culture also becomes a system of inherited concepts that are expressed in symbolic forms through which humans communicate, preserve, and develop their knowledge of life and attitudes towards life. The survival of this customary graduation tradition that is continuously carried out by the people of Lekuk 50 Tumbi Lempur as part of tradition and culture that they have and maintain. This tradition, nevertheless, must have its own meaning for the people here, as illustrated in the symbols contained in customary graduation tradition. With this symbol, the significance of this graduation tradition will be known as activities carried out. This tradition also act as a guideline for the actions conducted by Lekuk 50 Tumbi Lempur community.

\section{CONCLUSION}

Based on the results of this research and discussions described previously, it can be concluded that the traditional graduation tradition still exists in Lekuk 50 Tumbi Lempur community every second of Shawwal in the selected Multipurpose Village Building. Customary graduation tradition is still carried out until today since it has its own meaning by the people of Lekuk 50 Tumbi Lempur, including as a form of appreciation given by The Ten Leaders so that the sons and daughters of Lekuk 50 Tumbi Lempur can be proud of their achievements. In addition to the achievements and degrees that they have obtained through graduation in a customary manner, it was also a form of their degree recognition in the community. This title is expected to motivate the sons and daughters of Lekuk 50 Tumbi Lempur to be able to reach their goals and achieve success in the near future.

\section{ACKNOWLEDGEMENT}

Author would like to thank the General Director of Ministry of Research, Technology, and Higher Education for providing financial support to this research through the Beginner Lecturer Research Grant in 2019.

\section{REFERENCES}

Alimin, dkk. 2006. Adat dan Budaya Daerah Kerinci. Dinas Kebudayaan Kabupaten Kerinci.

Clifford Geertz. 1992. Tafsir Kebudayaan . Yogyakarta: Kanisius.

Friedman, Marilyn M. (1998). Keperawatan Keluarga Teori dan Praktik. Jakarta: EGC

Hamalik, O. 2004. Proses Belajar Mengajar. Jakarta: Bumi Aksara.

Haviland, A William. 1999. Antropologi . Jilid 2 Jakarta: Erlangga.

Hindar Hindaryatiningsih, Nanik. Model Proses Pewarisan Nilai-Nilai Budaya Lokal Dalam Tradisi Masyarakat Buton. Sosiohumaniora : Journal of sciences and Humanities. Vol 18. No. 2 Tahun 2016.

Kaplan, David, Albert A. Manners. 1999. Teori Budaya. Yogyakarta: Pustaka Pelajar. 
Koentjaraningrat. 1972. Beberapa Pokok Antropologi Sosial. Jakarta: Dian Rakyat.

Liliweri, Alo. 2014. Pengantar Studi Kebudayaan. Bandung; Nusamedia.

Linton, Ralph. 2008. Status Sosial Dan Kelas Sosial-Stratifikasi/Diferensiasi Dalam Masyarakat. Jakarta: Pustaka Pelajar.

Martina Dewi, Vera. Upacara Adat Wisuda Waranggono di Kayangan Api Desa Sendangharjo Kecamatan Ngasem Kabupaten Bojonegoro (Nilai Budaya dan Potensinya Sebagai Sumber Pembelajaran Sejarah). Jurnal Studi Sosial. Vol. 3 No. 2 Desember 2018.

Mayor Polak, YBAF.(1979). Sosiologi Suatu Buku Pengantar Ringkas. Jakarta: PT. Ikhtiar Baru.

Miles, M B dan Huberman, A M. 1992. Analisis Data Kualitatif : Buku Sumber Tentang Metode-Metode Baru. Terjemahan oleh Tjetjep Rohendi Rohidi. Jakarta : Penerbit Universitas Indonesia (UI-Press).

Ramadani, Yolla. Strid Qommaneeci. Pengaruh Pelaksanaan Kenduri Sko (Pesta Panen) Terhadap Perekonomian dan Kepercayaan Masyarakat Kerinci, Provinsi Jambi. JANTRO. Vol. 20, No. 1 Juni 2018.

Sugiyono. 2008. Memahami Penelitian Kualitatif. Bandung. ALFABETA.

Soekanto, Soerjono. (2007). Sosiologi Suatu Pengantar. Jakarta: Rajawali Pers.

Zakaria, Iskandar. 1984. Tambo Sakti Alam kerinci. Kabupaten Kerinci: Perpustakaan Kabupaten Kerinci 